\title{
Anxiolytic and anti-depressant effects of hydroalcoholic extract from Erythrina variegata and its possible mechanism of action
}

\author{
Hong-Biao Chu, Yue-De Tan, Yun-Jing Li, Bin-Bin Cheng, Bao-Qi Rao, Ling-Shan Zhou
}

Department of Pharmacy, School of Medicine, Jinggangshan University, Ji'an 343009, China

\begin{abstract}
Background: Erythrina variegata has been widely used as a traditional medicine.

Objective: The study was designed to evaluate the anxiolytic and anti-depressant effects of an extract from Erythrina variegata.

Methods: The extract was evaluated for anxiolytic and anti-depressant action using the elevated plus maze, light/dark box, open field, forced swimming and tail suspension tests in mice. The mechanism of action was further elucidated using high-performance liquid chromatography with fluorescence detection methods to assay the levels of five neurotransmitters in brain.

Results: The extract exhibited significant increase in the percentage of the open arms entries and the time spent in the open arms in the elevated plus maze test. The results of the light/dark box test revealed a significant increase in the amount of time spent in the light chamber. Extract- treated mice also produced significant increase in the number of crossings and rearings in the open field test.In the forced swimming and tail suspension tests, the extract was able to promote significant decrease in the immobility time. In addition, the extract significantly altered the levels of five neurotransmitters in the brain tissue.

Conclusion: These findings suggest that Erythrina variegata presents potential anxiolytic and anti-depressant activity, and the mechanism may be related to the alteration of neurotransmitter levels.

Keywords: Anxiolytic; anti-depressant; Erythrina variegata; elevated plus maze; forced swimming; neurotransmitters.

DOI: https://dx.doi.org/10.4314/ahs.v19i3.28

Cite as: Chu H-B, Tan Y-D, Li Y-J, Cheng B-B, Rao B-Q, Zhou L-S. Anxiolytic and anti-depressant effects of bydroalcoholic extract from Erythrina variegata and its possible mechanism of action. Afri Health Sci. 2019;19(3): 2526 -2536. https://dx.doi. org/10.4314/ahs.v19i3.28
\end{abstract}

\section{Introduction}

According to the World Health Organization report ${ }^{1}$, approximately 450 million people suffer from a mental or behavioral disorder. Depression and anxiety are two of the most common mental disorders, exacting a pervasive toll on the individual and impairing numerous aspects of quality-of-life by inducing physical, social, emotional, and occupational dysfunction ${ }^{2-5}$. The complexities of the central nervous system make diagnoses, treatment, and amelioration of these illnesses exceptionally difficult. In the etiology and pathophysiology of depressive disorders, chronic stress is one of the most important contributing factors ${ }^{6}$. This explains the strong comorbidity
Corresponding author:
Hong-Biao Chu,
Department of Pharmacy,
School of Medicine,
Jinggangshan University, Ji'an, 343009, China.
Email: hongbiaochu@163.com

between depression and anxiety ${ }^{7}$ and the similar efficacy of pharmacological therapies for both disorders ${ }^{8}$. However, because of the limited efficacy of current drugs, the need for newer, better-tolerated and more efficacious treatments remains high.

As a result, there has been increased interest in the use of complementary and alternative medicines (CAM) as a natural method for treating numerous types of anxiety and depression' ${ }^{9}$. In recent years, many traditional Chinese medicinal plants have been successfully used to prevent or treat anxiety and depression ${ }^{10}$.

The genus Erythrina (Fabaceae) consists of 110-200 tropical trees and shrubs, which are widely distributed in tropical and sub-tropical regions. The plants under the Erythrina genus are collectively known as "coral tree". It is typically found on sandy soil in littoral forest, and sometimes in coastal forest up to $250 \mathrm{~m}$ in elevation ${ }^{11}$. Many species of the Erythrina genus are used in folk medicines to treat central nervous system diseases, including E. velutina, E. mulungu and E. mysorensis, which present the sedative, neu-

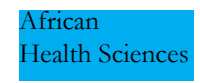

(C) 2019 Chu et al. Licensee African Health Sciences. This is an Open Access article distributed under the terms of the Creative commons Attribution License (https://creativecommons.org/licenses/BY/4.0), which permits unrestricted use, distribution, and reproduction in any medium, provided the original work is properly cited. 
romuscular blocking ${ }^{12}$, anti-nociceptive, anxiolytic and depressant activities ${ }^{13-19}$.

E. variegata is a medium sized deciduous small tree with prickly stems and branches, leaves with triangular leaflets and large coral red flowers and grows all over the tropics. In traditional medicine, different parts of E. variegata have been used to produce nervine sedation, febrifuge, anti-asthmatic, and anti-epileptic effects, and its leaves have been used for the treatment of patients with various conditions, such as liver ascites, convulsions, and arthritis, among other disorders. It has also been shown to have potential for treating patients with conditions such as fever, inflammation, bacterial infection, insomnia, helminthiasis, coughing, cuts, and wounds $\mathrm{s}^{20-23}$.

In view of all observations cited above, this influenced us to design and conduct the present study to evaluate the impact of alcoholic extract of E. variegata bark in different behavioral models in mice and to elucidate its mechanism of action. The anxiolytic- and antidepressant-like effects were assessed in the elevated plus maze, light/dark box, open field, forced swimming and tail suspension tests, respectively.

\section{Materials and methods}

\section{Plant material and extract preparation}

The bark of E. variegata L. (Leguminosae) was collected from the regions of Zhejiang Province of China in the month of September 2016, and identified from Department of Pharmacy of Jinggangshan University by Prof. Zhaochang Liang. The dried and powdered bark (100 g) of E. variegata was extracted three times with $95 \%$ alcohol $(300 \mathrm{~mL})$ under reflux for 3 hours. The resulting solvent was eliminated under reduced pressure to obtain a dried extract, with a yield of $18.5 \mathrm{~g} / 100 \mathrm{~g}$ of the starting crude material. The residue was dissolved in water for final suitable concentrations.

\section{Animals}

Male Kunming mice (18-22 g) were purchased from Hunan SJA Laboratory Animal Co., Ltd, and were fed a commercial diet and water ad libitum. The animals were housed in cages with food and water ad libitum and maintained on a natural $12 \mathrm{~h}$ of light and dark cycle. Ethical clearance for performing the experiments on animals was obtained from Institutional Animal Ethics Committee, School of Medicine, Jinggangshan University.

\section{Experimental design}

The anxiolytic activities were examined by using the elevated plus maze (EPM), light/dark box and open field tests. The forced swimming and tail suspension tests were performed to evaluate antidepressant activities. Animals were treated orally with the extract of E. variegata. Controls received vehicle (water) at the same volume $(10 \mathrm{~mL} /$ $\mathrm{kg}$ ) administered by the same route as the treated groups. Diazepam and fluoxetine, used as standards, were administered orally after dissolution in distilled water. The treatments of all groups were continued for 7 days. The mice were allowed to rest for $30 \mathrm{~min}$ after the last feeding. To each test, a total of 60 male mice were randomly divided into five groups of 12 mice each. The different groups were treated with: water (vehicle), extract (50, 100 and $200 \mathrm{mg} / \mathrm{kg}$ ), diazepam (DZP, $2 \mathrm{mg} / \mathrm{kg}$ ) or fluoxetine (FLU, $10 \mathrm{mg} / \mathrm{kg}$ ).

\section{Elevated plus maze test}

The elevated plus maze test for mice consisted of two perpendicular open arms $(30 \times 5 \mathrm{~cm})$ and two closed arms $(30 \times 5 \times 25 \mathrm{~cm})$ also in perpendicular position ${ }^{24}$. The open and closed arms were connected by a central platform $(5 \times 5 \mathrm{~cm})$. The entire apparatus was elevated $45 \mathrm{~cm}$ and four lights were placed above the maze. The mice were taken from their home cages and transported to the apparatus for $5 \mathrm{~min}$. The animal was placed at the center of the plus maze with its nose in the direction of one of the open arms. Entry into an arm was defined as the animal placing all four paws onto the arm. The percentage of the open arms entries $(\mathrm{OE} \%)$ and the percentage of the time spent in the open arms (OT\%) were recorded as the anxiety index. All tests sessions were taped by using a video camera. After each test, the maze was carefully cleaned up with a wet tissue paper (10\% ethanol solution).

\section{Light/dark box test}

The apparatus consisted of a cage having dimensions 21 $\mathrm{cm} \times 42 \mathrm{~cm} \times 25 \mathrm{~cm}$. A partition with door was placed to divide it into two sections of equal size. The first section was white and second was black colored. The light illumination in the first section was kept bright and second was dim. Each mouse was placed separately in the center place of white box while facing door present in the partition. The observation period of each animal was 5 min. All tests sessions were taped using a video camera. After each test, the maze was carefully cleaned up with a wet tissue paper (10\% ethanol solution). Anxiolytic ativ- 
ity was evaluated in terms of percentage of time spent in light and dark area ${ }^{25}$.

\section{Open field test}

The open field test was used to evaluate the exploratory activity of the animal for $5 \mathrm{~min}$. The apparatus consisted of a wooden box $(50 \times 50 \times 50 \mathrm{~cm})$. The arena of the open field was divided into 25 squares $(10 \times 10 \mathrm{~cm})$ of equal area. The experimental room was dark and sound attenuated. The open field arena was illuminated with a lamp, focusing on the field from a height of about 75-100 $\mathrm{cm}$. The mouse was placed in the central square and then the number of squares the mouse crossed was measured (crossing) and the number of times the mouse stood on hind limbs (rearing) was observed and recorded ${ }^{26}$.

\section{Forced swimming test}

The forced swimming test is the most widely used and recognized pharmacological model for assessing anti-depressant activity ${ }^{27}$. Briefly, mice were forced to swim individually in a glass cylinder (diameter $10 \mathrm{~cm}$, height 25 $\mathrm{cm}$ ), containing fresh water up to a height of $10 \mathrm{~cm}$ at $25 \mathrm{~cm}$. All animals were forced to swim for a $6 \mathrm{~min}$ period and the total duration of immobility was recorded during the last 4 min with a video camera. Mice were considered immobile when they floated in the water without struggling and making only those movements necessary to keep their heads above the water.

\section{Tail suspension test}

Mice were assessed in the tail suspension test, which was performed with a computerized device, allowing four animals to be tested at one time. In a chamber that was both acoustically and visually isolated, an individual mouse was suspended $50 \mathrm{~cm}$ above the floor by adhesive tape placed approximately $1 \mathrm{~cm}$ from the tip of the tail. Immobility time was recorded during the last 4 min of a total of 6 min session. Immobility was scored as a failure to make any struggling movements, and attempts to catch the adhesive tape or body torsions or jerks.

\section{Measurement of neurotransmitter levels}

Detections of the levels of dopamine, noradrenaline, serotonin, glutamate and gamma-aminobutyric acid (GABA) in brain were estimated by using high-performance liquid chromatography with fluorescence detection (HPLC-FD). After the end of behavioral experiments in EPM or forced swimming test, the mice were killed by decapitation and the brain was dissected immediately. After recording weight of the brain, it was frozen at $-80^{\circ} \mathrm{c}$ until analysis. Samples were homogenized in 2 $\mathrm{ml}$ of ice cold $0.6 \mathrm{M}$ perchloric acid and the resulting mixture was centrifuged at $10,000 \times \mathrm{g}$ for $15 \mathrm{~min}$ at $4{ }^{\circ} \mathrm{C}$. The supernatant was centrifuged again at $12,000 \times \mathrm{g}$ for 10 min at $4{ }^{\circ} \mathrm{C}$ and divided into $\mathrm{A}$ and $\mathrm{B}$ portions. Portion A was used for detections of the levels of dopamine, noradrenaline and serotonin and portion $B$ for glutamate and GABA. The instrument parameters used for HPLC-FD were as follows: Agilent chromatographic system, Diamonsil ODS column $(4.6 \mathrm{~mm} \times 250 \mathrm{~mm})$, mobile phase for portion A sample: methanol-buffer (buffer: $0.1 \mathrm{~mol}$ $\mathrm{NaAc}, 0.1 \mathrm{mmol}$ EDTA-2Na, $\mathrm{pH}$ 5.1) and for portion B sample: methanol-buffer (buffer: $50 \mathrm{mmol} \mathrm{NaAc}, 1 / 100$ (v/v) THF); flow rate: $1.0 \mathrm{~mL} / \mathrm{min}$; injection volume: 10 L; column temperature: $25^{\circ} \mathrm{c}$. Excitation and emission of the fluorescence detector were set to $290,330 \mathrm{~nm}$ for portion $\mathrm{A}$, and $338,425 \mathrm{~nm}$ for portion $\mathrm{B}$, respectively. The precolumn derivative reagent (phthalic aldehyde) was added into portion B sample before injection. Peaks were identified by comparing the retention time of sample and standard. The concentration of each neurotransmitter in the sample was analyzed according to their area under the curve using their straight-line equation. The levels of neurotransmitter were expressed as $\mathrm{ng} / \mathrm{g}$ (for dopamine, noradrenaline and serotonin) and $\mu \mathrm{g} / \mathrm{g}$ (for glutamate and GABA).

\section{Statistical analysis}

Expression of data was done as mean \pm standard error of mean (per group $n=12$ ). The normally distributed data were subjected to two-way ANOVA followed by Dunnett's test. $\mathrm{p}<0.05$ was considered statistically significant.

\section{Results}

\section{Elevated plus maze test}

In EPM test, the dose-effects of extract at 50, 100 and $200 \mathrm{mg} / \mathrm{kg}$ are shown in Figure 1. Compared with the vehicle group, the group of animals treated with diazepam (DZP) and the extract at 50 and $100 \mathrm{mg} / \mathrm{kg}$ showed significant increase $(\mathrm{p}<0.01$ or $\mathrm{p}<0.05)$ in the $\mathrm{OE} \%$ as well as OT\%. The $100 \mathrm{mg} / \mathrm{kg}$ group showed higher levels of $\mathrm{OE} \%(\mathrm{p}<0.05)$ than those of the 200 and $50 \mathrm{mg} /$ $\mathrm{kg}$ groups, indicating that $100 \mathrm{mg} / \mathrm{kg}$ dose is significantly more effective than those of other doses of the extract. No significant differences in the $\mathrm{OE} \%$ as well as $\mathrm{OT} \%$ were found between the $200 \mathrm{mg} / \mathrm{kg}$ group and vehicle 


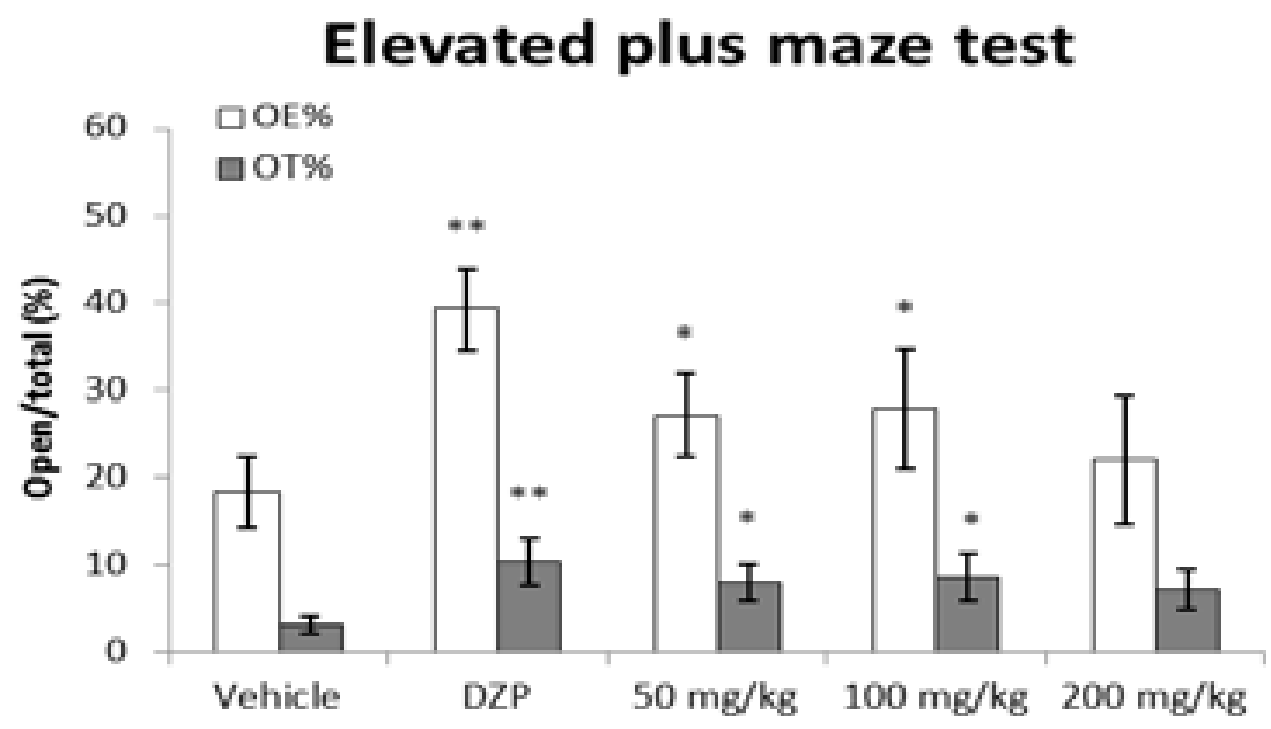

Figure 1: Anxiolytic effect of extract on the OE\% and OT\% of EPM mice.Mean $( \pm s)$ percentage of open arm entries (OE\%) or of time spent in the open arms (OT\%) in the mice placed at the center of a plus-maze and given a 5-min test. ${ }^{*} \mathrm{p}<0.05$ and ${ }^{* *} \mathrm{p}<0.01$ comparedwith the vehicle group.

\section{Open field test}

In the open field test, diazepam-treated mice showed significant increase $(p<0.01)$ in the number of squares crossed during 5-min interval of test as compared to vehicle-treated groups (Figure 3). Hydroalcoholic extract-treated mice at two doses (50 and $200 \mathrm{mg} / \mathrm{kg}$ ) produced significant increase in the number of crossings ( $\mathrm{p}$ $<0.05$ ). Extract-treated mice (50 and/or $100 \mathrm{mg} / \mathrm{kg}$ ) also produced significant increase in the number of rearings $(\mathrm{p}<0.01$ and/or $\mathrm{p}<0.05)$. No significant differences in the crossing times were found between the $100 \mathrm{mg} / \mathrm{kg}$ group and vehicle group. The significant differences in the rearing times were not found between the DZP, 200 $\mathrm{mg} / \mathrm{kg}$ groups and vehicle group. Extract at doses of 50 $200 \mathrm{mg} / \mathrm{kg}$ produced a lower level of the crossing times, when compared with the DZP group. However, extract at doses of 50 and $100 \mathrm{mg} / \mathrm{kg}$ produced a higher level of the rearing times, when compared with the DZP group.

\section{Forced swimming test}

To examine the possible anti-depressant-like effect of the extract, we subjected the mice to forced swimming test. As shown in Figure 4, the animal treated with fluoxetine (FLU, $10 \mathrm{mg} / \mathrm{kg}$ ) showed significant decrease $(\mathrm{p}<0.05)$ in the immobility time when compared to the vehicle group treated with water. Also, the mice treated with extract at 50, 100 and $200 \mathrm{mg} / \mathrm{kg}$ showed lower levels of immobility time. The $200 \mathrm{mg} / \mathrm{kg}$ group has lower level of immobility time $(\mathrm{p}<0.01)$ than those of the FLU, 50 and $100 \mathrm{mg} / \mathrm{kg}$ groups, indicating that $200 \mathrm{mg} / \mathrm{kg}$ dose is significantly more effective than those of other dose and fluoxetine $(10 \mathrm{mg} / \mathrm{kg})$. 


\section{Light/dark box test}

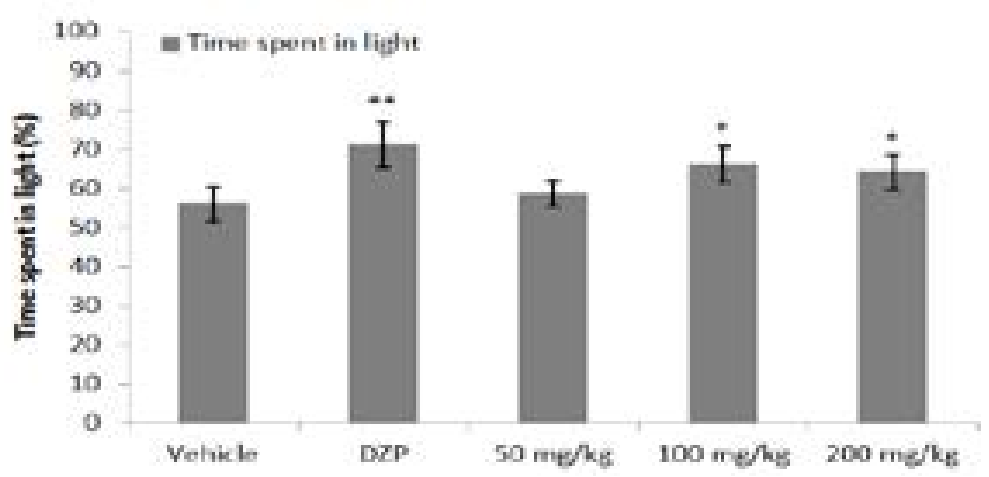

Figure 2:Anxiolytic effect of extract on performance in the light/dark box test. Mean $( \pm$ s)percentage of time spent in the light area in the mice placed at the light/dark box and given a 5 -min test. ${ }^{*} \mathrm{p}<0.05$ and ${ }^{* *} \mathrm{p}<0.01$ comparedwith the vehicle group.

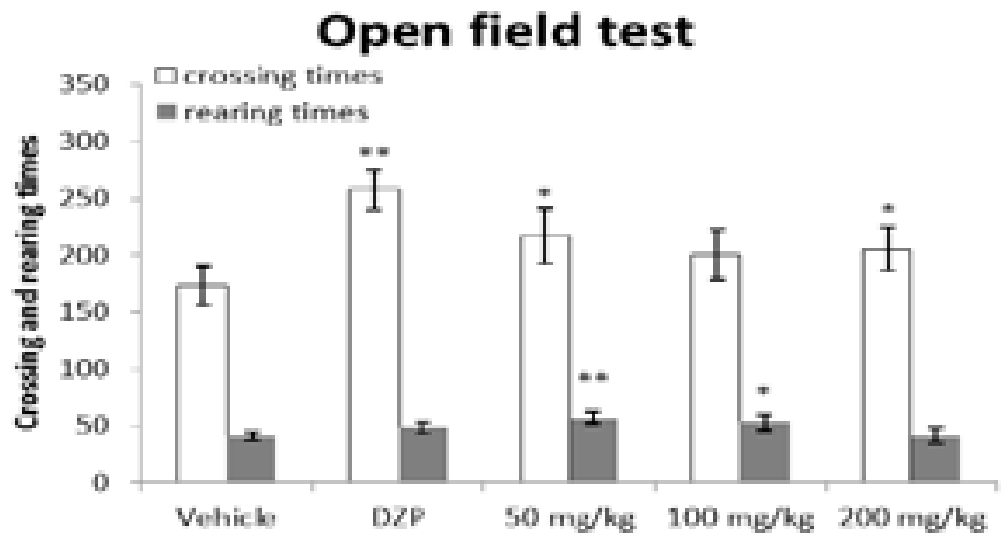

Figure 3: Anxiolytic effect of extract on performance in the open field test.Mean $( \pm s)$ number of squares the mouse crossed (crossing) and number of times the mouse stood on hind limbs (rearing) in the mice placed at the open field and given a 5 -min test. ${ }^{*} \mathrm{p}<0.05$ and ${ }^{* *} \mathrm{p}<0.01$ compared with the vehicle group.

\section{Forced swimming test}

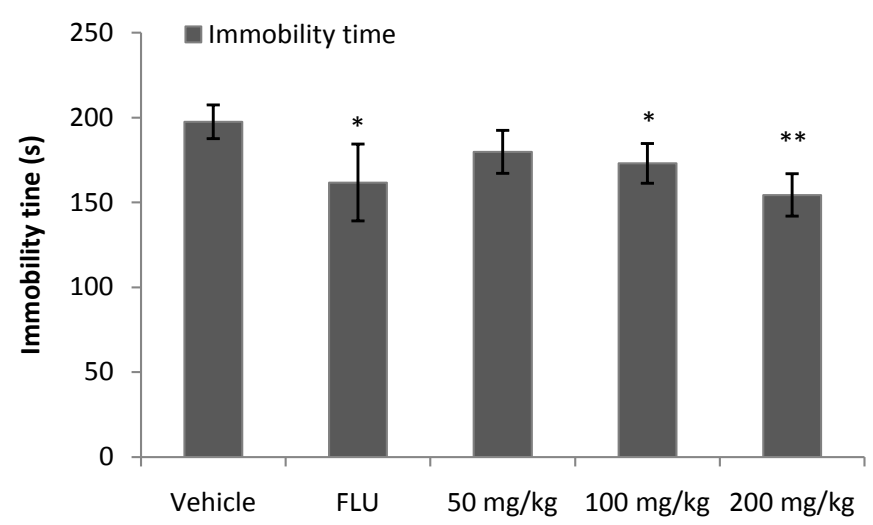

Figure 4:Antidepressanteffect of extract on performance in the forced swimming test. Mean $( \pm \mathrm{s})$ immobility time in the mice placed at the forced swimming test and given a final 4 min of the 6min test. ${ }^{*}<0.05$ and ${ }^{* *} \mathrm{p}<0.01$ compared with the vehicle group. 


\section{Tail suspension test}

Comparison between the effects of extract at various doses with respect to control vehicle and the standard drug fluoxetine has been presented in Figure 5. The extract $(50$ and $200 \mathrm{mg} / \mathrm{kg})$ significantly $(\mathrm{p}<0.05)$ decreased the immobility time as compared to control group. How- ever, the extract $(100 \mathrm{mg} / \mathrm{kg})$ did not show significant decline in immobility time. Fluoxetine treated mice showed greater decline in immobility time and showed significant $(\mathrm{p}<0.01)$ reduction in immobility time compared to control group. However, the extracts at doses of 50-200 mg/ $\mathrm{kg}$ produced a lower level of the immobility time, when compared with the FLU group.

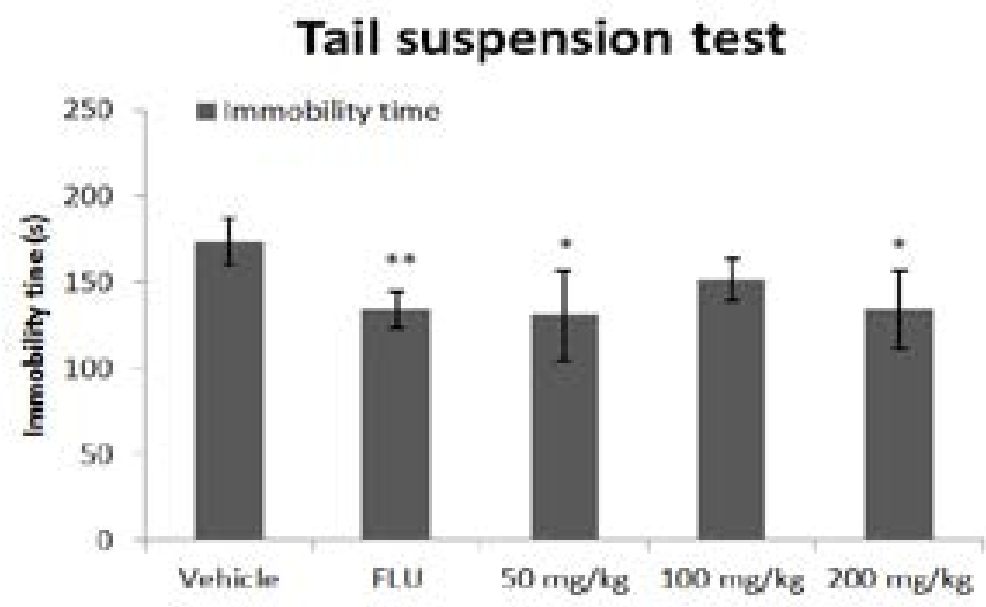

Figure 5: Antidepressanteffect of extract on performance in the tail suspension test.Mean $( \pm \mathrm{s})$ immobility time in the mice placed at the tail suspension test and given a final $4 \mathrm{~min}$ of the 6-min test. ${ }^{*} \mathrm{p}<0.05$ and ${ }^{* *} \mathrm{p}<0.01$ compared with the vehicle group.

\section{Measurement of neurotransmitter levels}

After the end of EPM behavioral experiments, the neurotransmitter levels of dopamine, noradrenaline, serotonin, glutamate and GABA, were quantified by HPLCFD in the brain of mice (Table 1). The diazepam (DZP) and $50 \mathrm{mg} / \mathrm{kg}$ dosage groups showed a decrease in levels of dopamine, and 100 and $200 \mathrm{mg} / \mathrm{kg}$ dosage groups had an increase in levels of dopamine when compared to the group treated with water. Moreover, in this test the effects of extract at dose of 50,100 , and $200 \mathrm{mg} / \mathrm{kg}$ indicated the effects that increased after 7 days of treatment.
The $50 \mathrm{mg} / \mathrm{kg}$ dosage groups showed similar decrease to levels of noradrenaline and serotonin. The effects of extract at dose of 50,100 , and $200 \mathrm{mg} / \mathrm{kg}$ presented a trend to increase the levels of noradrenaline and serotonin after 7 consecutive days of treatment. In addition, statistical analysis indicated a significant decrease $(p<0.01)$ in glutamate level in mice treated with extract at 50 and $100 \mathrm{mg} /$ $\mathrm{kg}$ dose. At the same time, the GABA levels in the above groups had obvious decrease $(p<0.05)$ when compared with vehicle group. The glutamate/GABA ratio showed significant decrease $(p<0.01)$ in the mice treated with diazepam and extracts (50 and $100 \mathrm{mg} / \mathrm{kg}$ ).

Table 1: The levels of dopamine, noradrenaline, serotonin, glutamate and GABA in brain tissue of mice in EPM

\begin{tabular}{|c|c|c|c|c|c|c|}
\hline Group & $\begin{array}{c}\text { dopamine } \\
\text { (ng/g) }\end{array}$ & $\begin{array}{c}\text { noradrenaline } \\
(\mathrm{ng} / \mathrm{g})\end{array}$ & $\begin{array}{l}\text { serotonin } \\
\text { (ng/g) }\end{array}$ & $\begin{array}{c}\text { glutamate } \\
(\mu \mathrm{g} / \mathrm{g})\end{array}$ & $\begin{array}{l}\text { GABA } \\
(\mu \mathrm{g} / \mathrm{g})\end{array}$ & glutamate/GABA \\
\hline Vehicle & $735.7 \pm 85.0$ & $771.7 \pm 88.9$ & $537.4 \pm 50.0$ & $1499.6 \pm 209.5$ & $3396.2 \pm 277.8$ & $0.44 \pm 0.05$ \\
\hline DZP & $713.1 \pm 68.5$ & $780.9 \pm 92.1$ & $541.1 \pm 86.7$ & $928.1 \pm 112.0^{* *}$ & $3041.6 \pm 232.2^{* *}$ & $0.31 \pm 0.03^{* *}$ \\
\hline $50 \mathrm{mg} / \mathrm{kg}$ & $679.6 \pm 84.4$ & $689.3 \pm 101.4$ & $509.6 \pm 66.8$ & $1104.7 \pm 218.0^{* *}$ & $3154.6 \pm 233.7^{*}$ & $0.35 \pm 0.06^{* *}$ \\
\hline $100 \mathrm{mg} / \mathrm{kg}$ & $764.6 \pm 123.4$ & $780.3 \pm 149.8$ & $527.1 \pm 54.3$ & $1104.7 \pm 284.4^{* *}$ & $3138.7 \pm 300.4$ & $0.35 \pm 0.07^{* *}$ \\
\hline $200 \mathrm{mg} / \mathrm{kg}$ & $823.4 \pm 113.7$ & $822.5 \pm 157.4$ & $584.1 \pm 91.9$ & $1218.4 \pm 295.1^{*}$ & $2974.4 \pm 454.0^{*}$ & $0.43 \pm 0.14$ \\
\hline
\end{tabular}

Data are presented as mean $\pm \operatorname{SE}(n=12) .{ }^{*} \mathrm{p}<0.05,{ }^{* *} \mathrm{p}<0.01$ vs. vehicle group 
Similarly, the above five neurotransmitter levels were quantified by HPLC-FD in the brain of mice after end of forced swimming test behavioral experiments (Table $2)$. The animal treated with diazepam $(2 \mathrm{mg} / \mathrm{kg})$ and extracts $(50,100$ and $200 \mathrm{mg} / \mathrm{kg})$ showed decrease in levels of dopamine and noradrenaline when compared to the mice treated with water; while the diazepam (DZP) group showed significant decrease $(\mathrm{p}<0.05)$ in level of dopamine. The levels of serotonin showed significant de- crease in diazepam treated and $100 \mathrm{mg} / \mathrm{kg}(\mathrm{p}<0.01)$ and $200 \mathrm{mg} / \mathrm{kg}(\mathrm{p}<0.05)$ extract treated groups compared to the vehicle group. On the other hand, the data indicated a significant decrease $(p<0.01)$ in glutamate level in mice treated with extract at 50 and $100 \mathrm{mg} / \mathrm{kg}$ dose. At the same time, the GABA levels in the above groups had obvious decrease when compared with vehicle group. The glutamate/GABA ratio showed significant decrease $(\mathrm{p}<0.01)$ in the mice treated with diazepam and extracts (50 and $100 \mathrm{mg} / \mathrm{kg}$ ).

Table 2: The levels of dopamine, noradrenaline, serotonin, glutamate and GABA in brain tissue of mice in forced swimming test

\begin{tabular}{ccccccc}
\hline Group & $\begin{array}{c}\text { dopamine } \\
(\mathrm{ng} / \mathrm{g})\end{array}$ & $\begin{array}{c}\text { noradrenaline } \\
(\mathrm{ng} / \mathrm{g})\end{array}$ & $\begin{array}{c}\text { serotonin } \\
(\mathrm{ng} / \mathrm{g})\end{array}$ & $\begin{array}{c}\text { glutamate } \\
(\mu \mathrm{g} / \mathrm{g})\end{array}$ & $\begin{array}{c}\text { GABA } \\
(\mu \mathrm{g} / \mathrm{g})\end{array}$ & glutamate/GABA \\
\hline Vehicle & $791.1 \pm 63.6$ & $949.8 \pm 147.0$ & $546.9 \pm 49.2$ & $1688.0 \pm 156.7$ & $2720.2 \pm 197.8$ & $0.62 \pm 0.05$ \\
FLU & $733.9 \pm 46.6^{*}$ & $842.7 \pm 91.4$ & $502.5 \pm 58.6^{*}$ & $1695.9 \pm 189.3$ & $2617.2 \pm 136.0$ & $0.65 \pm 0.05$ \\
$50 \mathrm{mg} / \mathrm{kg}$ & $732.5 \pm 162.5$ & $854.1 \pm 166.7$ & $549.7 \pm 92.8$ & $1329.4 \pm 272.6^{* *}$ & $2626.2 \pm 453.1$ & $0.51 \pm 0.10^{* *}$ \\
$100 \mathrm{mg} / \mathrm{kg}$ & $788.0 \pm 52.3$ & $909.2 \pm 71.4$ & $469.7 \pm 52.2^{* *}$ & $1318.1 \pm 241.7^{* *}$ & $2447.1 \pm 418.8$ & $0.54 \pm 0.05^{* *}$ \\
$200 \mathrm{mg} / \mathrm{kg}$ & $788.0 \pm 78.4$ & $864.5 \pm 76.6$ & $506.4 \pm 53.7^{*}$ & $1495.8 \pm 288.4$ & $2663.3 \pm 630.0$ & $0.55 \pm 0.13$ \\
\hline
\end{tabular}

Data are presented as mean $\pm \mathrm{SE}(\mathrm{n}=12) .{ }^{*} \mathrm{p}<0.05,{ }^{* *} \mathrm{p}<0.01$ vs. vehicle group

\section{Discussion}

The present work evaluated the anxiolytic and antidepressant activity of various doses of the extract of E. variegata in mice employing behavioral animal models, including the elevated plus maze, light/darbox, open field, forced swimming and tail suspension tests. These tests are classic and standard models for screening central nervous system actions providing information about anxiety and depressant performance. Animal models of anxiety and depression are typically based on exposure of animals to a stressful condition and a specific test for measuring behavioral and physiological responses ${ }^{28}$.

Both the EPM and light/dark box test have been widely used to evaluate neurobehavioral profiles of rodents under conditions of anxiety. In the EPM test, exposure animals upon to an open arm causes an approach conflict that is significantly robust than the response elicited by exposure to an enclosed arm of the maze. Thus, open/ enclosed arm entries and time spent in respective arms provide a measure of fear provoked by suppression of exploratory action. Generally, classical anxiolytic antagonizes these behavioral changes, and benzodiazepines are used to validate the anxiolytic activity. Similarly, in light/ dark box test, anxiety is generated by the conflict between the tendency to explore and the initial tendency to avoid the unfamiliar environment and can be evaluated accord- ing to the number of transitions in to and the time spent in the light chamber where an increase in these parameters is considered to reflect anxiolytic-like properties ${ }^{29}$. In the present work, a clear anxiolytic-like activity of a hydroalcoholic extract of E. variegata has been demonstrated. This extract was able to increase significantly the time spent and number of entries mice into the aversive arm of the plus-maze and light/dark box tests. These results indicate anxiolytic activity comparable with that produced by DZP, the standard anxiolytic drug.

The open field test is a standard neophobic test of anxiety. In this test, rodents naturally tend to avoid open spaces ${ }^{30}$. Thus, animals removed from their acclimatized cage and placed in environment express anxiety and fear, by showing alteration in all or some parameters. Anxiolytic treatments reduce such fearful behavior of animals in open field. Statistical analysis of the data obtained from these experiments supported anxiolytic-like activity of extracts at both the doses (50 and $100 \mathrm{mg} / \mathrm{kg}$ ) as its effect shows significant increase in the number of squares crossed and the number of rearings, as compared to the vehicle-treated group, which indicates its anxiolytic-like effect.

The forced swimming and the tail suspension tests are behavioral despair tests useful for probing the pathological mechanism of depression and for the evaluation of 
antidepressant drugs ${ }^{31}$. Characteristic behavior scored in both tests is termed immobility, reflecting a behavioral state of despair, as seen in human depression ${ }^{32}$. The effects of extract of E. variegata on the duration of immobility in the above mouse depressive models have showed that treating animals with the extract orally for 7 days reduced significantly the duration of immobility both in forced swimming and the tail suspension tests at the doses of 50,100 and $200 \mathrm{mg} / \mathrm{kg}$.

The dose-response relationship of extracts in the EPM, light/dark box, open field and forced swimming, tail suspension models appears to be rough bell-shaped. This explains why the $100 \mathrm{mg} / \mathrm{kg}$ dose appears to be superior to the 50 and $200 \mathrm{mg} / \mathrm{kg}$. This phenomenon remains poorly understood although many of the most important biological events show receptor desensitization.

To date, the biological explanations for many types of anxiety and depressant disorders remain inadequate. Postulations have implicated a dysregulation of specific neurotransmitters such as serotonin, dopamine and GABA as potential causes for both depression and anxiety disorders $^{33}$.

Alterations in the brain monoamines dopamine (DA) and serotonin (5-HT) have been implicated in the etiology and/or pharmacotherapy of multiple mental disorders including schizophrenia and depression. Serotonin is a monoamine neurotransmitter and is found predominantly in the gut, however is also synthesized in the central nervous system where it plays a role in regulating mood, memory and various other functions ${ }^{34}$. Noradrenergic hyperactivity has been established as a critical component of the stress response and abnormal noradrenergic signal is consistently implicated in anxiety related behavior $^{35}$. The diazepam (DZP) and $50 \mathrm{mg} / \mathrm{kg}$ dosage groups showed a decrease in levels of dopamine, and 100 and $200 \mathrm{mg} / \mathrm{kg}$ dosage groups had an increase in levels of dopamine when compared to the group treated with water. Moreover, in this test the effects of extract at dose of 50 , 100 , and $200 \mathrm{mg} / \mathrm{kg}$ presented a trend to increase after 7 consecutive days of treatment. The $50 \mathrm{mg} / \mathrm{kg}$ dosage groups showed similar decrease to levels of noradrenaline and serotonin. The effects of extract at dose of 50, 100, and $200 \mathrm{mg} / \mathrm{kg}$ presented a trend to increase the levels of noradrenaline and serotonin after 7 consecutive days of treatment. Results indicated that extract decreased the levels of dopamine, noradrenaline and serotonin in mice, suggesting that the extract has a regulating effect on monoamine neurotransmitters after central nervous system disorder and it might be one of the anxiolytic or anti-depressant functional mechanism.

Multiple lines of evidence strongly implicate glutamate in anxiety and depressant disorders. There are abnormal levels of glutamate and various glutamate receptor classes in the brains of patients with anxiety disorders, and glutamate levels are altered in rodents by stressors ${ }^{36}$. Glutamate is the most abundant excitatory neurotransmitter in the brain, and acts pre- and postsynapticallyby activating diverse receptors characterized by their structural properties. Glutamate ionotropic and metabotropic receptors regulate neurotransmission across excitatory synapses, and modulate several physiological brain functions such as synaptic plasticity, learning, and memory ${ }^{37}$. The present results showed that, compared to the vehicle group, the levels of glutamate in 50 and $100 \mathrm{mg} / \mathrm{kg}$ dose groups had different decrease $(p<0.01)$, which suggest that the anxiolytic and anti-depressant effect of E. variegata was possibly involved in the decrease of glutamate level (Table 1 and 2). In addition, GABA is known as an inhibitory neurotransmitter present almost exclusively in the central nervous system, and GABAergic dysfunction causes mood disorders or neurological disorders such as seizures, anxiety, and depression ${ }^{38}$. Our present study showed that the levels of GABA in standard and extract dose groups had obvious decrease, when compared to the vehicle group treated with water. It might be speculated that the net effect of this reduction in GABA concentrations would be to reduce the overall inhibitory influence of GABA on neural circuits involved in responding to stress or threat ${ }^{39}$.

GABA is synthesized from glutamate by removal of an $\alpha$-carboxyl group by glutamic acid decarboxylase. The synthetic relationship between GABA and glutamate suggests that concentrations of each may be influenced by the other ${ }^{40}$. As shown in Table 1 and 2, the glutamate/ GABA ratio showed significant decrease in the mice treated with standard and extract, when compared to the vehicle group. The experimental data implied further the anxiolytic and depression effect of E. variegata was possibly involved in the alteration of glutamate and GABA levels. However, the precise mechanism underlying this change still requires further investigations.

Some studies showed that phytochemicals like alkaloids, 
flavonoids, phenolic acids, lignans, cinnamates, terpenes and saponins possess anxiolytic effects in a wide range of animal models of anxiety ${ }^{41}$. The inhibitory effects of flavonoids on monoamine oxidases have attracted great interest, since alterations in monoaminergic transmission are reported to be related to neurodegenerative diseases such as Parkinson's and ADs and psychiatric disorders such as depression and anxiety, thus monoamine oxidases may be considered as targets for the treatment of these multi-factorial diseases ${ }^{42}$.

Erythrina plants are known to produce alkaloids, flavonoids, and terpenes ${ }^{43-45}$. Three isolated alkaloids from $E$. mulungu plants have shown anxiolytic effects in different animal models ${ }^{46}$. The natural flavonoids compound luteolin has been reported to have anti-depressant, anti-nociceptive and anxiolytic-like effects, which possibly involve the mechanisms of modulating GABA signaling ${ }^{47}$.Preliminary phytochemical studies on E. variegata exposed the presence of carbohydrates, protein, alkaloids, steroids, phytosterols, terpenoids, saponin, glycosides, tannins and phenols, isoflavonesand flavonoids ${ }^{48-51}$. The current display of anxiolytic and anti-depressant activity may be related to E. variegata ingredients, but the exact relationship needs further investigation.

\section{Conclusion}

The hydroalcoholic extract of the bark of E. variegata possesses anxiolytic and anti-depressant properties in mice. The alteration of neurotransmitters level was observed in present study, which is possibly involved in mediating anxiolytic and anti-depressant action. Further investigations are warranted for elucidating the exact mechanism and bioactive compounds responsible for the observed effects.

\section{Acknowledgments}

This work was supported by the National Natural Science Foundation of China (31260084) and Natural Science Foundation of Jiangxi Province (20142BAB205024).

\section{Conflict of interest}

The authors report no conflicts of interest. The authors alone are responsible for the content and writing of the paper.

\section{References}

1. Sayers J. The world health report 2001 - Mental health: new understanding, new hope. Bull World Health Organ. 2001; 79: 1085-1085. [View Article]
2. Mendlowicz MV, Stein MB. Quality of life in individuals with anxiety disorders. Am J Psychiat. 2000; 157: 669682. [PubMed]

3. Kessler RC, Berglund P, Demler O, Jin R, Koretz D, Merikangas KR et al. The epidemiology of major depressive disorder. JAMA. 2003; 289: 3095-3105. [View Article]

4. Mathers CD, Loncar D. Projections of global mortality and burden of disease from 2002 to 2030. PLoS Med. 2006; 3: e442. [View Article]

5. Ferrari AJ, Charlson FJ, Norman RE, Patten SB, Freedman G, Murray CJ et al. Burden of depressive disorders by country, sex, age, and year: findings from the global burden of disease study 2010. PLoS Med. 2013; 10: e1001547. [View Article]

6. Belmaker RH, Agam G. Major depressive disorder. N Engl J Med. 2008; 358: 55-68. [PubMed]

7. Muller MB, Wurst W. Getting closer to affective disorders: the role of CRH receptor systems. Trends Mol Med. 2004; 10: 409-415. [PubMed]

8. Baldwin DS, Anderson IM, Nutt DJ, Bandelow B, Bond A, Davidson JR et al. Evidence-based guidelines for the pharmacological treatment of anxiety disorders: recommendations from the British Association for Psychopharmacology. J Psychopharmacol. 2005; 19: 567-596. [PubMed]

9. Wang R, Xu Y, Wu HL, Li YB, Li YH, Guo JB, et al. The antidepressant effects of curcumin in the forced swimming test involve 5-HT1 and 5-HT2 receptors. Eur J Pharmacol. 2008; 578: 43-50. [PubMed]

10. He DY, Wang XT, Zhang P, Luo XX, Li XY, Wang LL, et al. Evaluation of the anxiolytic and anti-depressant activities of the aqueous extract from Camellia euphlebia Merr. ex Sealy in mice. Evid Based Complement and Alternat Med. 2015; 2015, Article ID 618409, 1-8. [View Article] 11. Kumar A, Lingadurai S, Jain A, Barman N. Erythrina variegata Linn: A review on morphology, phytochemistry and pharmacological aspects. Pharmacog Rev. 2010; 4: 147152.

[View Article]

12. Dantas MC, De Oliveira FS, Bandeira SM, Batista JS, Silva CD, Alves PB, et al. Central nervous system effects of the crude extract of Erythrina velutina on rodents. $J$ Ethnopharmacol. 2004; 94: 129-133. [PubMed]

13. Vasconcelos SMM, Lima NM, Sales GTM, Cunha GMA, Aguiar LMV, Silveira ER, et al. Anticonvulsant activity of hydroalcoholic extracts from Erythrina velutina and Erythrina mulungu. J Ethnopharmacol. 2007; 110: 271274. [PubMed]

African Health Sciences Vol 19 Issue 3, September, 2019 
14. Vasconcelos SMM, Macedo DS, Melo CT, Paiva Monteiro A, Rodrigues AC, Silveira ER, et al. Central activity of hydroalcoholic extracts from Erythrina velutina and Erythrina mulungu in mice. J Pharm Pharmacol. 2004; 56: 389-393. [PubMed]

15. Vasconcelos SMM, Oliveira GR, Carvalho MM, Rodrigues ACP, Silveira ER, Fonteles MFM, et al. Antinociceptive activities of the hydroalcoholic extracts from Erytrhrina velutina and Erythrina mulungu in mice. Biol Pharm Bull. 2003; 26: 946-949. [View Article]

16. Onusic GM, Nogueira RL, Pereira AM, Flausino OA Jr, Viana MB. Effects of chronic treatment with a water-alcohol extract from Erythrina mulungu on anxiety-related responses in rats. BiolPharm Bull. 2003; 26: 15381542. [View Article]

17. Ribeiro MD, Onusic GM, Poltronieri SC, Viana MB. Effect of Erythrina velutina and Erythrina mulungu in rats submitted to animal models of anxiety and depression. Braz.J Med Biol Res.2006; 39: 263-270. [PubMed] 18. Raupp IM, Sereniki A, Virtuoso S, Ghislandi C, Cavalcanti E Silva EL, Trebien HA, et al. Anxiolytic-like effect of chronic treatment with Erythrina velutina extract in the elevated plus-maze test. J Ethnopharmacol. 2008; 118: 295299. [PubMed]

19. Nagaraja TS, Mahmood R, Krishna V, Thippeswamy BS, Veerapur VP. Evaluation of anxiolytic effect of Erythrina mysorensis Gamb. in mice. Indian J Pharmacol. 2012; 44: 489-492. [PubMed]

20. Shahriar M, Khair NZ, Sheikh Z, Chowdhury SF, Kamruzzaman M, Bakhtiar MSI, et al. Phytochemical analysis, cytotoxic and in vitro anti-oxidant activity of Erythrina variegate Bark. Eur J Med Plants. 2016; 11: 1-5. [View Article]

21. Rahman MZ, Sultana SJ, Faruquee CF, Ferdous F, Rahman MS, Islam MS et al. Phytochemical and biological investigations of Erythrina variegata. Saudi Pharm J. 2007; 15: 140-145. [View Article]

22. Haque R, Ali MS, Saha A, Allimuzzaman M. Analgesic activity of methanolic extract of the leaf of Erythrina variegata. J Pharm Sci. 2006; 5: 77-79. [View Article]

23. Sahoo K, Panda SS, Das D, Dhal NK. In vitro analysis of antimicrobial activity of stem extracts of Erythrina variegata L: a useful medicinal plant. Int J Pharm Bio Sci. 2012; 3: 766-772. [View Article]

24. Lister RG. Ethologically-based animal models of anxiety disorders. Pharmacol Ther. 1990; 46: 321-340. [PubMed]
25. Bourin M, Hascoët M. The mouse light/dark box test. Eur J Pharmacol. 2003; 463: 55-65. [PubMed]

26. Arias C, Pautassi RM, Molina JC, Spear NE. A comparison between taste avoidance and conditioned disgust reactions induced by ethanol and lithium chloride in preweanling rats. Dev Psychobiol. 2010; 52: 545-557. [View Article]

27. Porsolt RD, Le Pichon M, Jalfre M. Depression: a new animal model sensitive to antidepressant treatments. $\mathrm{Na}$ ture. 1977; 266: 730-732. [PubMed]

28. Palanza P. Animal models of anxiety and depression: how are females different? Neurosci Biobehav Rev. 2001; 25: 219-233. [PubMed]

29. Crawley J, Goodwin FK. Preliminary report of a simple animal behavior for the anxiolytic effects of benzodiazepines. Pharmacol Biochem Behav. 1980; 13: 167-170. [PubMed]

30. Prut L, Belzung C. The open field as a paradigm to measure the effects of drugs on anxiety-like behaviours: a review. Eur J Pharmacol. 2003; 463: 3-33. [PubMed] 31. Porsolt RD, Bertin A, Jalfre M. Behavioral despair in rats and mice: strain differences and the effects of imipramine. Eur J Pharmacol. 1978; 51: 291-294. [PubMed] 32. Steru L, Chermat R, Thierry B, Simon P. The tail suspension test: a new method for screening antidepressants in mice. Psychopharmacology (Berl). 1985; 85: 367-370. [PubMed]

33. Christmas D, Hood S, Nutt D. Potential novel anxiolytic drugs. Curr Pharm Des. 2008; 14: 3534-3546. [PubMed] 34. Berger M, Gray JA, Roth BL. The expanded biology of serotonin. Annu Rev Med. 2009; 60: 355-366. [PubMed] 35. Bremner JD, Krystal JH, Southwick SM, Charney DS. Noradrenergic mechanisms in stress and anxiety: I. preclinical studies. Synapse. 1996; 23: 28-38. [PubMed] 36. Krystal JH, Mathew SJ, Souza DC, Garakani A, Gunduz-Bruce H, Charney DS. Potential psychiatric applications of metabotropic glutamate receptor agonists and antagonists. CNS Drugs. 2010; 24: 669-693. [PubMed] 37. Collingridge GL, Bliss TV. Memories of NMDA receptors and LTP. Trends Neurosci. 1995; 18: 54-56. [PubMed]

38. Brambilla P, Perez J, Barale F, Schettini G, Soares JC. GABAergic dysfunction in mood disorders. Mol Psychiatr. 2003; 8: 721-737. [PubMed]

39. Hasler G, Veen JW, Grillon C, Drevets WC, Shen J. Effect of acute psychological stress on prefrontal GABA concentration determined by proton magnetic resonance 
spectroscopy. Am J Psychiatry. 2010; 167: 1226-1231. [View Article] 40. Cai KJ, Nanga RPR, Lamprou L, Schinstine C, Elliott M, Hariharan $\mathrm{H}$, et al. The impact of gabapentin administration on brain GABA and glutamate concentrations: A 7T 1H-MRS study. Neuropsychopharmacology. 2012; 37: 2764-2771. [PubMed]

41. Farzaei MH, Bahramsoltani R, Rahimi R, Abbasabadi F, Abdollahi M. A systematic review of plant-derived natural compounds for anxiety disorders. Curr Top Med Chem. 2016; 16: 1924-1942. [PubMed]

42. Turkmenoglu FP, Baysal I, Ciftci-Yabanoglu S, Yelekci K, Temel H, Pasa S, et al. Flavonoids from Sideritis Species: human monoamine oxidase (hMAO) inhibitory activities, molecular docking studies and crystal structure of xanthomicrol. Molecules. 2015; 20: 7454-7473. [PubMed] 43. Garcia-Mateos R, Soto-Hernandez M, Kelly D. Alkaloids from six Erythrina species endemic to Mexico. Biochem Syst Ecol. 1998; 26: 545-551. [ResearchGate]

44. Sarragiotto MH, Filho HL, Marsaioli A J. Erysotrine-N-oxide and erythrartine-N-oxide, two novel alkaloids from Erythrina mulungu. Can J Chem. 1981; 59: 2771-2775. [View Article]

45. Mckee TC, Bokesch HR, McCormick JL, Rashid MA, Spielvogel D, Gustafson KR, et al. Isolation and characterization of new anti-HIV and cytotoxic leads from plants, marine, and microbial organisms. J Nat Prod. 1997; 60: 431-438. [PubMed]

46. Setti-Perdigao P, Serrano MAR, Flausino OA Jr, Bolzani VS, Guimaraes MZP, Castro NG. Erythrina mulungu alkaloids are potent inhibitors of neuronal nicotinic receptor currents in mammalian cells. PLoS One. 2013; 8: e82726. [View Article]

47. Shen ML, Wang CH, Chen RY, Zhou N, Kao ST, Wu DC. Luteolin inhibits GABAA receptors in HEK cells and brain slices. Sci Rep. 2016; 6: 27695. [View Article] 48. Sato M, Tanaka H, Fujiwara S, Hirata M, Yamaguchi $\mathrm{R}$, Etoh $\mathrm{H}$, et al. Antibacterial property of isoflavonoids isolated from Erythrina variegata against cariogenic oral bacteria. Pbytomedicine. 2002; 9: 427-433. [PubMed]

49. Tanaka H, Etoh H, Shimizu H, Makita T, Tateishi Y. Two new isoflavonoids from Erythrina variegata. Planta Med. 2000; 66: 578-579. [PubMed]

50. Sato M, Tanaka H, Yamaguchi R, Kato K, Etoh H. Synergistic effects of mupirocin and an isoflavanone isolated from Erythrina variegata on growth and recovery of methicillin-resistant Staphylococcus aureus. Int J Antimicrob Agents. 2004; 24: 241-246. [PubMed]

51. Tanaka H, Hirata M, Etoh H, Shimizu H, Sako M, Murata J, et al. Eryvarins F and G, two 3- phenoxychromones from the roots of Erythrina variegata. Phytochemistry. 2003; 32: 1243-1246. [PubMed] 